\title{
Note on Pterygotus anglicus Agassiz (Eurypterida: Devonian) from the Campbellton Formation, New Brunswick
}

\author{
Randall F. Miller \\ Steinhammer Palaeontology Laboratory, New Brunswick Museum, \\ 277 Douglas Avenue, Saint John, New Brunswick E2K 1E5, Canada
}

Date Received June 5, 1995

Date Accepted December 28, 1995

\begin{abstract}
Fragments of the large eurypterid Pterygotus, recently collected from the Devonian Campbellton Formation at Atholville, New Brunswick, are identified as belonging to $P$. anglicus Agassiz. The only previous Pterygotus specimens from this site, collected in 1881 , were assigned to a new species $P$. atlanticus Clarke and Ruedemann, in 1912. Clarke and Ruedemann's suggestion that $P$. atlanticus might turn out to be a small specimen of $P$. anglicus is supported by this new find. However, possible revision of $P$. atlanticus awaits the discovery of additional, more complete, material.

On a déterminé que les fragments du grand euryptéride Pterygotus récemment recueillis dans la Formation dévonienne de Campbellton à Atholville, Nouveau-Brunswick, appartenaient au P. anglicus Agassiz. Les seuls spécimens antérieurs de Pterygotus de cet emplacement, prélevés en 1881 , avaient été attribués à une nouvelle espèce, le $P$. atlanticus, par Clarke et Ruedemann, en 1912. Cette nouvelle découverte appuie l'hypothèse de Clarke et Ruedemann à l'effet que le $P$. atlanticus pourrait en réalité constituer un petit spécimen de $P$. anglicus. La révision possible de la nature du $P$. atlanticus nécessitera néanmoins la découverte de matériel supplémentaire plus complet.
\end{abstract}

[Traduit par la rédaction]

\section{INTRODUCTION}

Among reports of rare occurrences of eurypterids in New Brunswick, two descriptions of Pterygotus exist. Pterygotus sp., collected in 1881 from the Devonian Campbellton Formation at Atholville (Whiteaves, 1883), was later described as $P$. atlanticus Clarke and Ruedemann (1912). A second specimen, Pterygotus sp., collected before 1909 from the Devonian at Dalhousie, was figured by Clarke (1909). The two occurrences are easily confused since the Campbellton specimen, P. atlanticus, is referred to as Pterygotus sp. prior to 1912 and described as being from the Dalhousie Formation, New Brunswick. The reference to Ells (1883) used by some authors for Pterygotus sp. from Dalhousie (Copeland and Bolton,1960; Kjellesvig-Waering, 1964) should be applied to Pterygotus atlanticus, since it is clear that in his report on field work for 1881, Ells (1883) was referring to the same Campbellton specimens described by Whiteaves (1883).

The Devonian Campbellton Formation exposed at Atholville, New Brunswick has been well known as a source of ostracoderm, arthrodire and acanthodian fish (Whiteaves, 1883; Woodward, 1892; Traquair, 1893) since the first fossils were discovered in 1881 (Whiteaves, 1889). In addition to the eurypterid and fish, the fauna includes molluscs and plants. This paper reports on new specimens of Pterygotus from the Atholville site that provide additional evidence to supplement four fragments already known. Two new partial specimens of chelae, the greatly enlarged pincerlike chelicerae that help distinguish Pterygotus from other eurypterids, are much larger than those previously described from Atholville and are assigned to $P$. anglicus Agassiz (1844).

\section{LOCATION AND STRATIGRAPHY}

The specimens described here were recovered from calcareous shale or mudstone of the Devonian (Emsian) Campbellton Formation (Williams et al., 1985) exposed on the bank of the Restigouche River at Atholville $\left(47^{\circ} 59^{\prime} 45^{\prime \prime} \mathrm{N}\right.$; $66^{\circ} 42^{\prime} 50^{\prime \prime} \mathrm{W}$, Fig. 1). The Atholville beds (Dineley and Williams, 1968) are exposed for over $2 \mathrm{~km}$ from west of the New Brunswick-Quebec bridge to midway between Pratt Point and Ferguson Point (Fig. 1). They are composed of a steeply inclined basal coarse breccia overlain by a succession of interbedded sandstones and shales. A total thickness of about $15 \mathrm{~m}$ is exposed. The Campbellton Formation unconformably overlies volcanics of the Lower Devonian Dalhousie Group. The unconformable upper contact with the overlying Carboniferous Bonaventure Formation (Williams et al., 1985) is beneath the Restigouche River (Dineley and Williams, 1968). The Atholville beds are covered by slump and vegetation in places and have not been described in detail. Plans to examine the stratigraphy and paleoenvironment of the Atholville section are currently underway. Only general comments are provided here in anticipation of a larger scale project.

The new specimens described here were collected near the west end of the Atholville exposure. At the fossil locality about $12 \mathrm{~m}$ of section is exposed (Fig. 2). Approximately $7 \mathrm{~m}$ of light brown mudstone alternating with plant-rich buff-coloured sandstone is overlain by about $4 \mathrm{~m}$ of dark grey mudstone and almost $2 \mathrm{~m}$ of brown to black mudstone. One specimen of Pterygotus was collected in situ in the upper $30 \mathrm{~cm}$ of the dark grey mudstone, about $10.5 \mathrm{~m}$ west of 


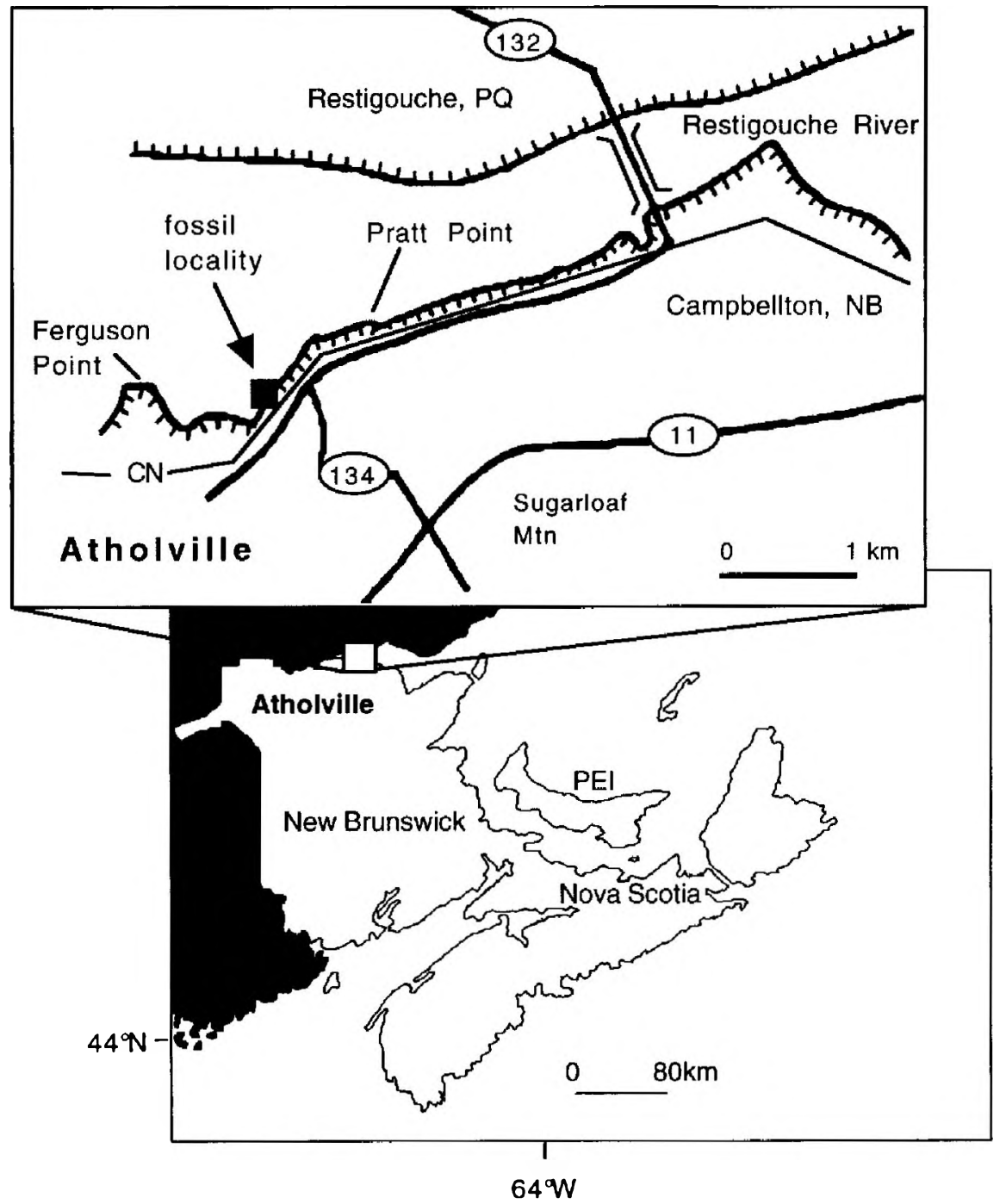

Fig. 1. Location of the Atholville beds, northern New Brunswick showing the Pterygotus anglicus Agassiz fossil locality.

a drainpipe. The other two specimens were recovered from the same rock type from a single slab of float on the beach about $9 \mathrm{~m}$ west of the drainpipe.

\section{Systematic PALAEONTOLOGY}

Various classification schemes for pterygotids have been used and currently five genera are recognized: Acutiramus, Erettopterus, Pterygotus, Truncatiramus and Jaekelopterus. The classification used by Kjellesvig-Waering (1964) and reviewed by Plotnick and Baumiller (1988) is used here.

Class Merostomata Dana, 1852

Subclass Eurypterida Burmeister, 1843

Family Pterygotidae Clarke and Ruedemann, 1912

Genus Pterygotus Agassiz, 1844

Pterygotus anglicus Agassiz, 1844

(Fig. 3a-c)

Material: Three specimens on two slabs. A free ramus of the chelicera, NBMG $9774 / 1$ and an incomplete unidenti- fied fragment, possibly a paddle (?) NBMG 9774/2. A free ramus of the chelicera, NBMG 9775. All specimens are deposited in the New Brunswick Museum (NBMG).

Description: The larger of the two free rami of the chelicerae, NBMG 9774/1 (Fig. 3a), is $135 \mathrm{~mm}$ long. Width of free ramus at centre of central tooth, $18 \mathrm{~mm}$. The order and size of dentition and tapering aspect of the chelicerae matches that of $P$. anglicus as described by Kjellesvig-Waering (1964) from the Lower Devonian of Scotland. Much of the cuticle has been removed and the specimen is partly buried by matrix. The smaller free rami of the chelicerae, NBMG 9775 (Fig. 3b), is 95 to $100 \mathrm{~mm}$ long. Width of free ramus at centre of central tooth, $10 \mathrm{~mm}$. The third unidentified fragment, NBMG $9774 / 2$ (Fig. 3c) may be a partial paddle, the distal segment of the swimming leg. It measures $33 \mathrm{~mm}$ at the widest point.

Horizon and Locality: Preserved in dark grey mudstone. Devonian (Emsian), Atholville, on bank of Restigouche River, New Brunswick; collected by R.F. Miller, September 30, 1994. NBMG 9774/1,2 found as loose block on beach about $1 \mathrm{~m}$ 


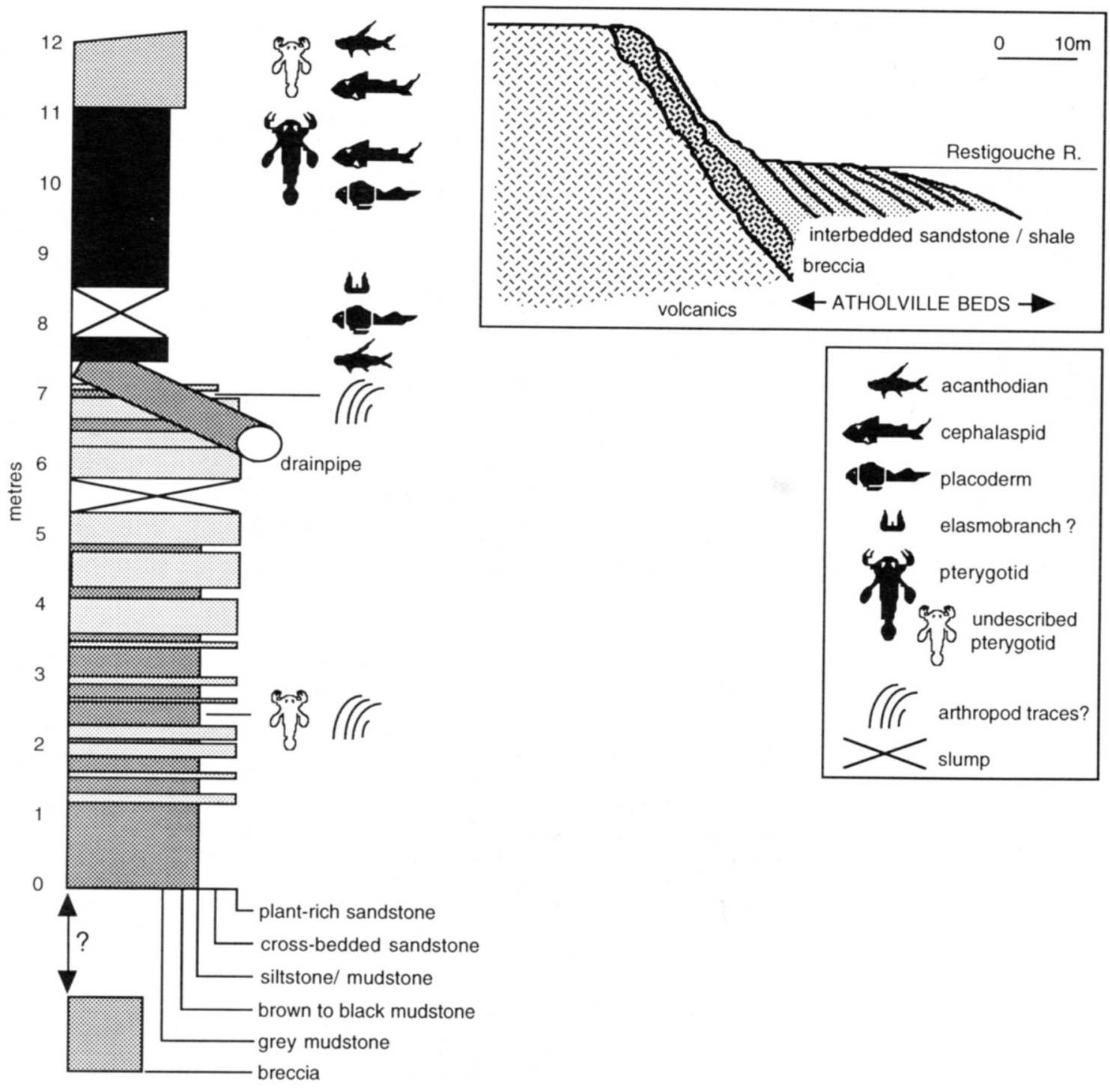

Fig. 2. Generalized stratigraphic section at Pterygotus anglicus Agassiz fossil locality in the Campbellton Formation, at the western exposure of the Atholville beds (after Dineley and Williams, 1968), Atholville, New Brunswick. Occurrences of pterygotid (including undescribed specimens), fish and arthropod trace fossils noted.

from outcrop and about $1.5 \mathrm{~m}$ from in situ specimen NBMG 9775.

Remarks: Specimen NBMG $9774 / 1$ is a large free ramus of the chelicera and suggests a specimen of considerable size. The specimen is similar to $P$. anglicus Agassiz from Balruddery, Forfarshire, Scotland (Kjellesvig-Waering, 1964, pl. 54, fig. 5) which was estimated to have reached a length of $1.7 \mathrm{~m}$ from the anterior of the prosoma to the posterior end of the telson. NBMG 9775 appears to represent a smaller specimen of the same species, about 1 to $1.2 \mathrm{~m}$ long.

\section{Discussion}

Eurypterid remains are rare in New Brunswick, having been described from only three localities: the Devonian Campbellton Formation at Atholville (Pterygotus anglicus, P. atlanticus), the Devonian at Dalhousie (Pterygotus sp.), and the Pennsylvanian Lancaster Formation at Fern Ledges,
Saint John (Eurypterella ornata, Eurypterus pulicaris, and Eurypterus sp.) (Copeland and Bolton, 1960). The Pennsylvanian specimens are poorly preserved and their affinity is uncertain. A fourth specimen from Fern Ledges, Belinuropsis wigudensis (Matthew, 1910), has also been considered a possible, but doubtful eurypterid (Miller, 1995).

Specimens of Pterygotus first noted by Whiteaves (1883) from Atholville were described by Clarke and Ruedemann (1912) and assigned to a new species $P$. atlanticus, a species designation which continued to be used (Russell, 1947, 1954; Kjellesvig-Waering, 1964) although not without some doubt as to its validity (Pageau, 1969). Their brief description was based on three fragments, a chelicera (Fig. 4a), the coxa of a swimming leg (Fig. 4b), and a fragment of metastoma (Fig. 4c) (catalogued as syntypes, GSC 3239, 3239a-c; Fulton, 1966). The free ramus of $P$. atlanticus (GSC 3239) measures at least $50 \mathrm{~mm}$ long and has a width at centre of central tooth of $7 \mathrm{~mm}$, suggesting an animal about $65 \mathrm{~cm}$ in length from anterior of the prosoma to the posterior end of 


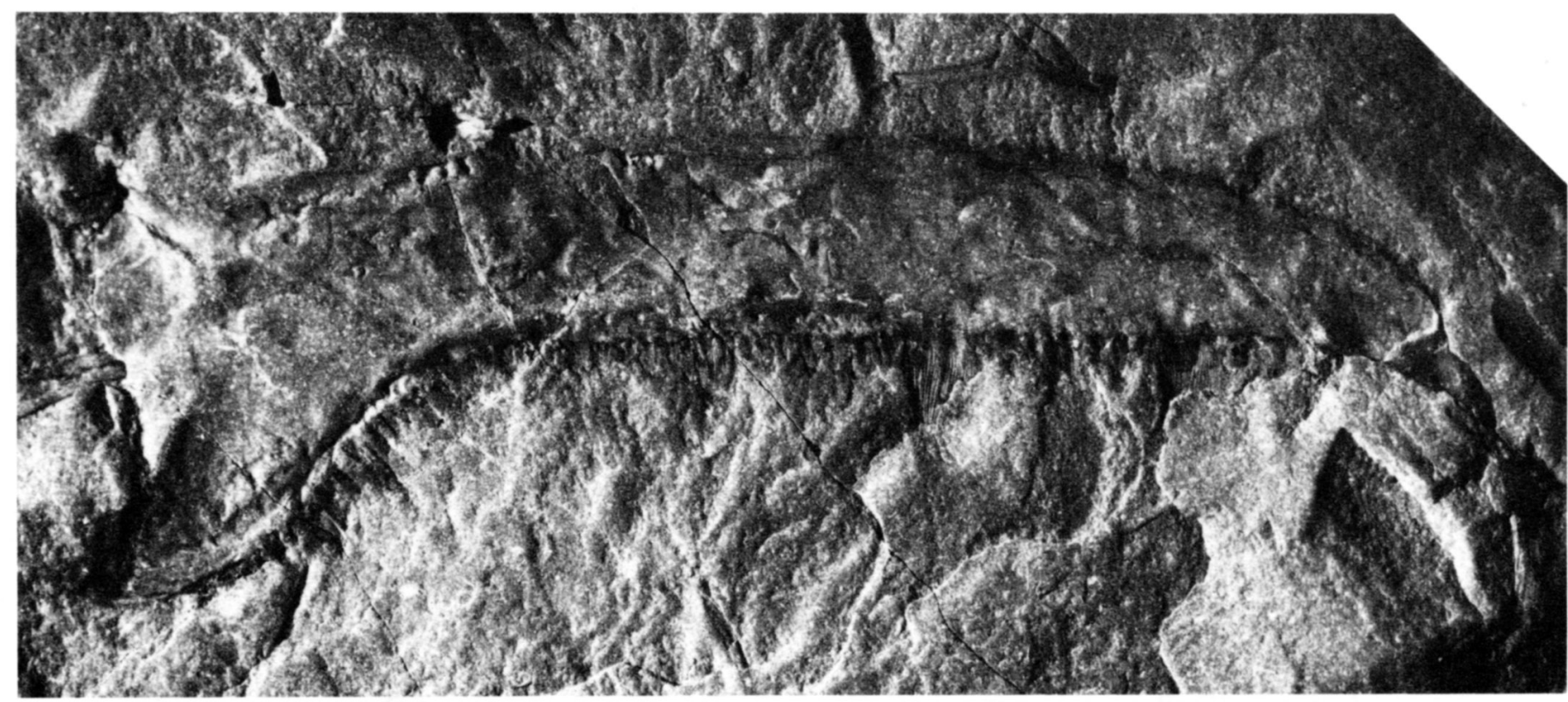

a

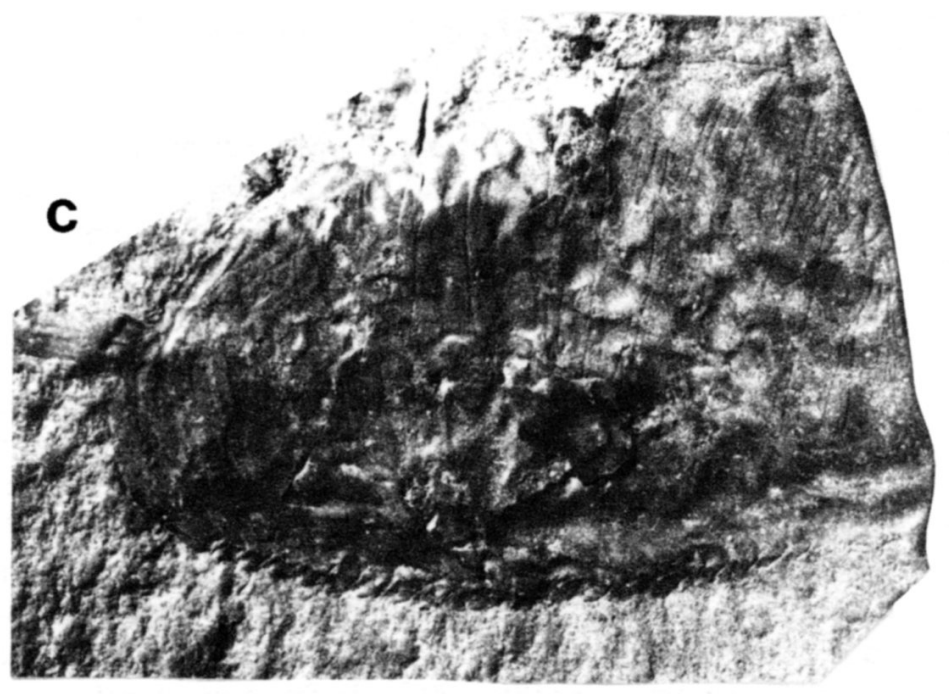

Fig. 3. Pterygotus anglicus Agassiz, Devonian, Campbellton Formation, Atholville, New Brunswick. (a) free ramus, NBMG 9774/ $1, x 1.3$, (b) free ramus, NBMG 9775, x 1.3, (c) unidentified fragment, possibly a paddle NBMG 9774/2, x 1.7. 

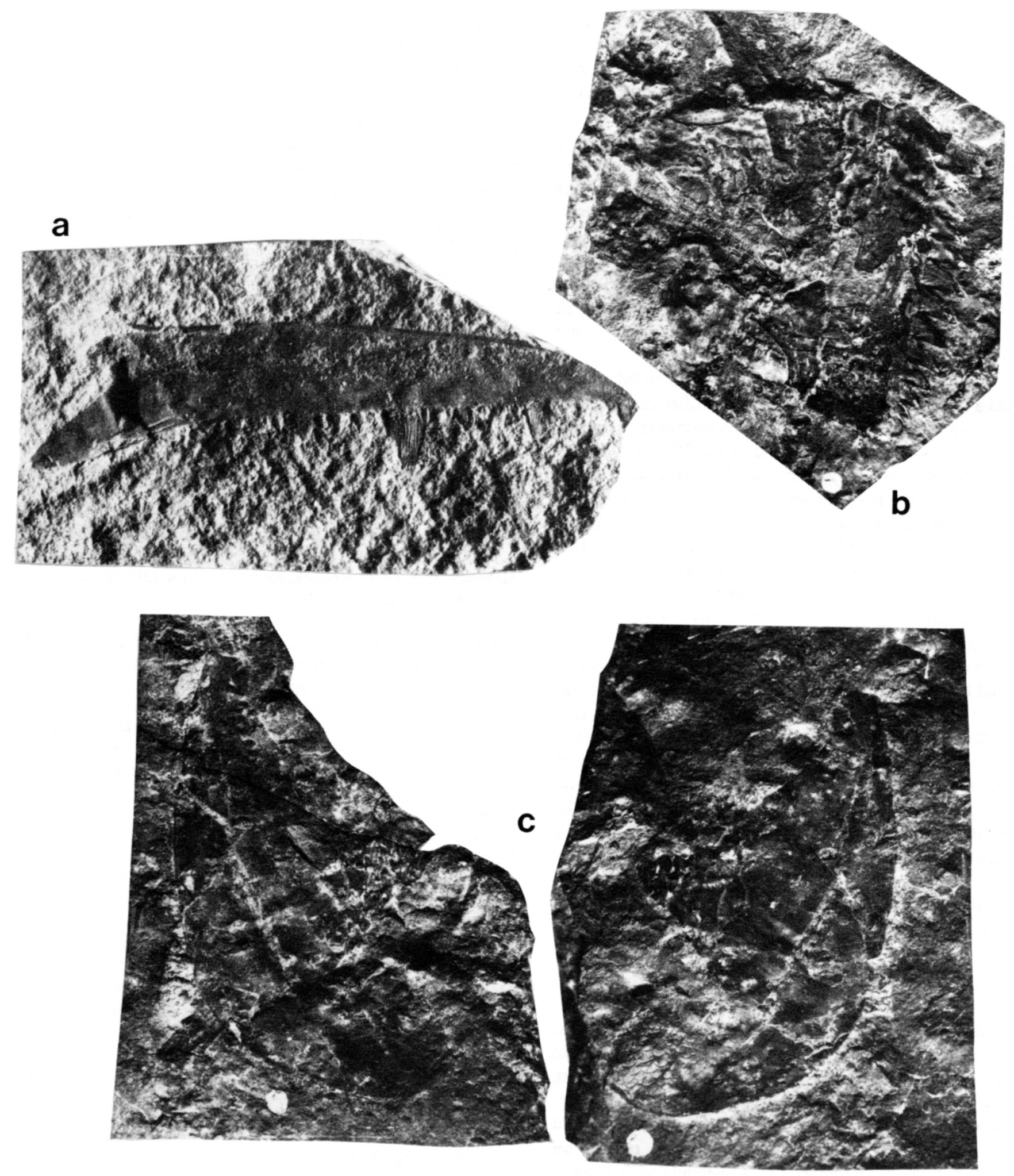

Fig. 4. Pterygotus atlanticus Clarke and Ruedemann, Devonian, Campbellton Formation, Atholville, New Brunswick. (a) free ramus GSC 3239, x 2.2 (whitened with ammonium chloride), (b) coxa of swimming leg, GSC 3239b, x 1.5, (c) metastoma part and counterpart, GSC 3239a (right), GSC 3239c (left), x 1.8.

the telson. Clarke and Ruedemann $(1912$, p. 358$)$ considered $P$. atlanticus to be "of considerable dimensions" and compared it with Pterygotus anglicus Agassiz. They suggested that with larger collections the species might prove to be "a vicarious form" of $P$. anglicus. Considering the new specimens described here as $P$. anglicus, Clarke and Ruedemann's suspicions were likely correct. The dimensions and dentition of the $P$. atlanticus chelicera (Fig. 4a) appear very similar to $P$. anglicus. Revision of $P$. atlanticus is probably necessary but redescribing $P$. atlanticus without additional 
material would more likely add confusion. It is unknown which unit specimens of $P$. atlanticus were collected from, but the lithology is the same as that of NBMG 9774 and NBMG 9775. This dark grey shale is found in only the upper part of the section (Fig. 2).

The three chelicera fragments of Pterygotus recovered so far from Atholville probably all belong to one species and indicate three individual animals with total length (prosoma to telson) ranging from $65 \mathrm{~cm}$ to $1.7 \mathrm{~m}$. Clarke and Ruedemann (1912) believed the majority of eurypterid remains found are the cast exuviae from the frequent moulting of individuals, and Kjellesvig-Waering (1964, p. 332) considered Pterygotus to be "definitely gregarious, at least during ecdysis" which may account for a wide range of sizes of individuals from one small locality.

In addition to pterygotid remains the slab NBMG 9774 contains a headshield fragment of an unidentified cephalaspid. Spines of an acanthodian, possibly Gyracanthus incurvus, occurred nearby NBMG 9775 and also on GSC $3239 \mathrm{~b}$ (Fig. 4b). Associations of Pterygotus and fish have been noted previously (Kjellesvig-Waering, 1961, 1964), the common belief being that Pterygotus was one of the chief predators in middle Paleozoic world. Evidence suggests, however, that the chelicerae were adapted for cutting and grasping, not crushing, a morphology as consistent with scavenging or browsing as with predation (Kjellesvig-Waering, 1964; Plotnick and Baumiller, 1988).

The most complete summary of fish remains from Atholville compiled by Gardiner (1966), with names updated here, includes Cephalaspis acadica, C. jexi, Yvonaspis campbelltonensis, Phlyctaenius acadicus, P. atholi, Climatius latispinosus, Cheiracanthus costellatus, Homacanthus gracilis, Gyracanthus incurvus, Doliodus problematicus and Mesacanthus semistriatus. The paleoenvironment of the Atholville beds is uncertain. Williams et al. (1985) describe it as a fluvial sequence. However, pterygotids, the composition of the fish fauna and the presence of terrestrial plant detritus suggest that at least part of the sequence may represent a lagoon or estuarine environment, if not marine.

\section{ACknowledgements}

Thanks to N. Parent and M. Arsenault, Parc du Miguasha, and R. Cloutier, Université des Sciences et Technologies de Lille, for sharing their knowledge about the Atholville site on a rainy afternoon; to J. Dougherty at the Geological Survey of Canada, Ottawa, for the loan of type specimens; and to the many palaeontologists who answered my request on PaleoNet for eurypterid references. M. Copeland and D. Rudkin provided helpful comments in their review of the manuscript.

Agassiz, L. 1844. Monographie des poissons fossiles du vieux grès rouge, ou système dévonien: Neutchâtel, folio.

Bolton, T.E. 1966. Catalogue of the Type Invertebrate Fossils of the Geological Survey of Canada, Volume III. Geological Survey of Canada, Ottawa, 203 p.

Burmeister, H. 1843. Die Organisation der Trilobiten, aus ihren lebenden Verwandten entwickelt; nebst einer systematischen Uebersicht aller zeither beschriebenen Arten. G. Reimer, Berlin, I-XII, pp. 1-148.
Clarke, J.M. 1909. Early Devonic History of New York and Eastern North America. New York State Museum, Memoir 9, Part II, $250 \mathrm{p}$.

Clarke, J.M. and Ruedemann, R. 1912. The Eurypterida of New York. New York State Museum, Memoir 14, 356 p.

Copeland, M.J. and Bolton, T.E. 1960. The Eurypterida of Canada. Geological Survey of Canada, Bulletin 60, pp. 13-47.

DANA, J.D. 1852. United States Exploring Expedition during the years $1838,1839,1840,1841,1842$, under the command of Charles Wilkes, U.S.N. Volume 13, Crustacea, pt. 1, pp. 1685; Volume 14, Crustacea, pt. 2., pp. 691-1618.

Dineley, D.L. and Williams, B.P.J. 1968. The Devonian continental rocks of the Lower Restigouche River, Quebec. Canadian Journal of Earth Sciences, 5, pp. 945-953.

Ells, R.W. 1883. Report on the Geology of northern and eastern New Brunswick and the north side of the Bay of Chaleurs. Geological Survey of Canada, Report of Progress 1880-82, p. $10 \mathrm{D}$.

Gardiner, B.G. 1966. Catalogue of Canadian fossil fishes. Royal Ontario Museum Life Sciences Contribution 68. University of Toronto Press, Toronto, 154 p.

KJellesvig-Waering, E.N. 1961. Eurypterids of the Devonian Holland Quarry shale of Ohio. Fieldiana, Geology, 14, pp. 79-98.

..... 1964. A synopsis of the family Pterygotidae Clarke and Ruedemann, 1912 (Eurypterida). Journal of Paleontology, 38, pp. 331-361.

Matthew, G.F. 1910. Remarkable forms of the Little River Group. Transactions of the Royal Society of Canada, 3, pp. 115133.

Miller, R.F. 1995. The status of Belinuropsis wigudensis Matthew, 1910, a Pennsylvanian merostome from New Brunswick, Canada. Atlantic Geology, 31, pp. 117-118.

Pageau, Y. 1969. Nouvelle faune ichthyologique du Dévonien moyen dans les Grès de Gaspé (Québec). II. Morphologie et systématique. Première section: A. Euryptérides, B. Ostracodermes, C. Acanthodiens et sélaciens. Le Naturaliste canadien, 96 , pp. $399-478$.

Plotnick, R.E. and Baumiller, T.K. 1988. The pterygotid telson as a biological rudder. Lethaia, 21, pp. 13-27.

Russell, L.S. 1947. New locality for fossil fishes and eurypterids in the Middle Devonian of Gaspé, Quebec. Royal Ontario Museum, Palaeontology Contributions 12, 4 p.

..... 1954. A new species of eurypterid from the Devonian of Gaspé. Annual Report of the National Museum of Canada, Bulletin 132, pp. 83-91.

TraquaIR, R.H. 1893. Notes on the Devonian Fishes of Campbelltown and Scaumenac Bay in Canada - No. 2. Geological Magazine, 10, pp. 145-149.

Whiteaves, J.F. 1883. On some fossil fishes, Crustacea and Mollusca from the Devonian rocks at Campbellton, N.B., with description of five new species. Canadian Naturalist and Quarterly Journal of Science, 10, pp. 93-101.

---- 1889. The Devonian System in Canada. American Geologist, 24, pp. 210-221.

Williams, G.L., FyfFe, L.R., Wardle, R.J., Colman-Sadd, S.P., and Boehner, R.C. 1985. Lexicon of Canadian Stratigraphy, Volume VI, Atlantic Region. Canadian Society of Petroleum Geologists, Calgary, 572 p.

Woodward, A.S. 1892. On the Lower Devonian Fish-Fauna of Campbellton, New Brunswick. Geological Magazine, 9, pp. $1-6$. 